\title{
ZAGROŻENIA KORUPCYJNE W RELACJACH MIĘDZY LEKARZEM A PACJENTEM
}

\section{CORRUPTION RISKS IN RELATIONS BETWEEN DOCTOR AND PATIENT}

\author{
Zakład Nauk Humanistycznych w Medycynie Pomorskiego Uniwersytetu Medycznego w Szczecinie \\ ul. Żołnierska 48, 71-210 Szczecin \\ Kierownik: dr n. hum. Tadeusz Dyk \\ ${ }^{1}$ Zakład Historii Medycyny i Etyki Lekarskiej Pomorskiego Uniwersytetu Medycznego w Szczecinie \\ ul. Rybacka 1, 70-204 Szczecin \\ Kierownik: dr hab. n. med. Aleksandra Kładna
}

\begin{abstract}
Summary
The article describes the problem of corruption occurring in the relationship between doctor and patient.

The doctor-patient relationship, including the provision of health services, is one of several potential areas of corruption in the health care system. Among the reasons for the existence of corruption in these relationships are the need to obtain better health care for the patient, and higher earnings in the case of a doctor.

Indications of corruption are utilitarian (action for personal advantage without ethical aspects), but may also be (actually or in the patient's opinion) the only way to obtain services and save health and even life.

Corruption between the doctor and the patient can be limited by better organization of the health care system, including the financing of benefits and education of medical personnel and patients, as well as traditional legal measures, such as prevention or the application of criminal sanctions.
\end{abstract}

K e y w o r d s: corruption - the doctor-patient relationship - health system - health care.

\section{Streszczenie}

Celem pracy było ukazanie zjawiska korupcji zachodzącego w relacjach między lekarzem a pacjentem.

Relacja lekarz-pacjent obejmująca udzielanie świadczenia zdrowotnego jest jednym z kilku potencjalnych obszarów korupcji w systemie ochrony zdrowia. Powodem zaistnienia korupcji we wspomnianych relacjach może być potrzeba uzyskania lepszej opieki zdrowotnej w przypadku pacjenta bądź wyższych zarobków w przypadku lekarza.

Przesłanki korupcji mają charakter utylitarny (działanie na swoją korzyść z pominięciem aspektów etycznych), ale mogą też być (w rzeczywistości bądź w mniemaniu pacjenta) jedyną drogą uzyskania świadczenia i ratowania zdrowia, a nawet życia.

Na ograniczanie zjawiska korupcji między lekarzem a pacjentem może mieć wpływ lepsza organizacja systemu zdrowotnego obejmująca sektor finansowania świadczeń oraz edukację kadr medycznych i pacjentów, a także tradycyjne środki prawne - prewencja czy stosowanie sankcji karnych.

H a s $\nmid$ a: korupcja - relacja lekarz-pacjent - system zdrowotny - opieka zdrowotna.

\section{Geneza korupcji}

Jako korupcję określa się wymianę korzyści, czyli jej przyjęcie przez jedną stronę za działanie na korzyść drugiej strony. Korzyścią może być dobro materialne (pieniądze, rzeczy) lub niematerialne (usługa, przysługa). Podstawową korzyścią w systemie ochrony zdrowia jest opieka zdrowotna, którą otrzymuje pacjent, a w przypadku lekarza jest to korzyść materialna. Korupcja jest powszechnie uważana za naganną moralnie, lecz istnieją okoliczności, które zachęcają do jej podejmowania. Należą do nich: poczucie braku określonego dobra, braku satysfakcji z posiadanego dobra bądź przekonanie, że bez udziału korupcji nie można tego dobra otrzymać. Okoliczności te mogą powodować, że zarówno biorący bezpośredni udział w procederze 
korupcji, jak i społeczeństwo usprawiedliwiają działanie korupcyjne. W systemie ochrony zdrowia główną przesłanką korupcji jest więc popyt na opiekę zdrowotną (zbyt duży w stosunku do jej podaży).

Pierwotny warunek pojawienia się korupcji to arbitralność, czyli możliwość podejmowania przez kogoś decyzji dotyczącej drugiej osoby i jednocześnie zdecydowania o uzyskaniu korzyści przez tę osobę. Arbitralności towarzyszy zazwyczaj brak przejrzystości reguł podejmowania decyzji.

Drugi warunek dotyczy kwestii straty poniesionej w wyniku korupcji. Nie ponosi jej ten, kto podejmuje arbitralne decyzje. Strata jest przede wszystkim publiczna, a więc rozkłada się na wszystkich podatników.

Powyższe warunki powodują, że środowiskiem korupcjogennym jest głównie sektor publiczny. W korupcji dochodzi zazwyczaj do konfliktu interesów, w którym interes prywatny przeważa nad publicznym. Obserwowany coraz częściej (również w systemie zdrowotnym) rozwój biurokracji i rosnące kompetencje urzędników decydujących o coraz większych obszarach życia publicznego mogą zwiększać potencjalne pole korupcji.

\section{Rodzaje korupcji w systemie ochrony zdrowia}

W systemie ochrony zdrowia występują współzależne podmioty. Należą do nich: świadczeniodawcy (lekarze, szpitale czy inne podmioty lecznicze), świadczeniobiorcy (pacjenci), płatnicy (ubezpieczyciele lub fundusze zarządzające środkami na finansowanie opieki zdrowotnej) oraz przemysł medyczny (producenci leków i sprzętu medycznego, apteki). Pomiędzy tymi podmiotami zachodzą różne systemowe relacje stwarzające potencjalne obszary zagrożeń korupcyjnych. Pierwszy potencjalny obszar korupcji dotyczy strategicznego poziomu polityki zdrowotnej, czyli sektora finansowania ochrony zdrowia. Dotyczy on relacji między płatnikiem a pozostałymi elementami sytemu. Relacja między publicznym płatnikiem a świadczeniodawcą jest związana z wyceną, ustalaniem warunków i kontraktowaniem świadczeń, a relacja między płatnikiem i przemysłem medycznym z kwestią refundowania leków i wyrobów medycznych. Korupcja występuje też na niższym poziomie polityki zdrowotnej obejmującym kontakty świadczeniodawców, pacjentów i przemysłu medycznego.

\section{Korupcja w polskim systemie ochrony zdrowia}

Wśród przestępstw korupcyjnych ściganych w polskim kodeksie karnym i dotyczących systemu zdrowotnego można wyróżnić kilka rodzajów sytuacji. Odnoszą się one do osób zatrudnionych w jednostkach organizacyjnych i dysponujących środkami publicznymi. W ochronie zdrowia mogą być to zarówno urzędnicy (przedstawiciele ministerstwa bądź płatnika), jak i lekarze pracujący w publicznym sektorze świadczeniodawców.
Pierwszy typ korupcji to łapownictwo. Łapownictwo bierne określone jest jako sprzedajność (art. 228), czyli przyjmowanie łapówki przez świadczeniodawcę zarówno od pacjenta, jak i przemysłu medycznego. Artykuł 229 jako przestępstwo definiuje łapownictwo czynne, czyli przekupstwo lub samo złożenie oferty przekupstwa przez przedstawiciela przemysłu medycznego w stosunku do świadczeniodawcy (dotyczące stosowania określonego leku czy sprzętu medycznego). Według artykułu 231 wyróżnia się kolejne rodzaje korupcji: nadużycie służbowe, przekroczenie uprawnień i niedopełnienie obowiązków służbowych zarówno przez urzędnika, jak i lekarza. W tej kategorii przestępstw można wymienić największą liczbę zachowań korupcyjnych.

W przypadku urzędnika mogą to być nieprawidłowości związane z rejestracją i refundacją leków lub kontraktowaniem świadczeń, a także nepotyzm. W przypadku lekarzy nieprawidłowości te mogą dotyczyć przepisywania leków (sugerowanych przez producenta medycznego), nakłaniania pacjenta przez lekarza do dodatkowych wizyt w prywatnym gabinecie lekarskim, sugerowania pacjentowi dania łapówki poprzez obniżanie standardów opieki.

W artykule 271 wymienia się przestępstwo poświadczenia nieprawdy, czyli działanie lekarza fałszywie orzekającego o stanie zdrowia badanego, związane z orzecznictwem rentowym lub uzyskaniem przez pacjenta „lewego” zwolnienia lekarskiego. W artykule 296 wymieniona jest natomiast korupcja gospodarcza, która może dotyczyć nieuczciwej konkurencji lub działania na niekorzyść podmiotu gospodarczego, którym może być świadczeniodawca lub producent medyczny (artykuł ten jest związany z art. 231) [1].

Według statystyk w postępowaniach korupcyjnych prowadzonych w Polsce w 2009 r. wśród osób zatrudnionych na kierowniczych stanowiskach podejrzanych i oskarżonych o przestępstwa korupcyjne w szpitalach, innych zakładach opieki zdrowotnej (obecnie podmiot leczniczy), bądź instytutach medycznych znalazło się 2417 osób oraz 33 osoby z centrali i oddziałów regionalnych Narodowego Funduszu Zdrowia (NFZ) [2]. Powyższe dane wskazują, że problem korupcji w ochronie zdrowia nie jest marginalny. O skali problemu może też świadczyć fakt, że służba zdrowia znalazła się w raporcie pt. „Przewidywane zagrożenia korupcyjne w Polsce” przygotowanym przez Centralne Biuro Antykorupcyjne (CBA) jako jeden z najważniejszych obszarów zagrożonych korupcją z punktu widzenia interesów ekonomicznych państwa [3].

W sprawozdaniu CBA za 2012 r. wśród wszystkich obszarów tematycznych, w których prowadzono postępowania przygotowawcze, te dotyczące służby zdrowia i farmacji stanowiły 6\% wszystkich przypadków (najwięcej $25 \%$ dotyczyło samorządu terytorialnego) [4].

\section{Podłoże korupcji w relacjach między lekarzem a pacjentem}

Zaistnieniu potencjalnych sytuacji korupcyjnych w relacjach między świadczeniodawcami a świadczeniobiorcami 
sprzyja wielość zadań, które może wykonywać lekarz w systemie ochrony zdrowia. Sytuacje te dotyczą przekupstwa (biernego ze strony lekarza i czynnego ze strony pacjenta). W ujęciu socjologicznym lekarz jest czynnikiem kontroli społecznej, który kwalifikuje pacjenta na leczenie, a także prowadzi je, decydując o przeprowadzonych procedurach medycznych i stosowanych lekach. Lekarz może także orzekać o stanie zdrowia pacjenta, występując jako urzędnik. Jako pierwotną przyczynę powodującą zaistnienie korupcji w relacjach między lekarzem a pacjentem można określić niski poziom opieki zdrowotnej, czyli jej niewystarczającą dostępność oraz jakość. Dostępność opieki zdrowotnej oznacza możliwość skorzystania ze świadczenia zdrowotnego w czasie choroby. Ograniczenia w dostępie do opieki są spowodowane niewystarczającą ilością środków finansowych przeznaczanych na świadczenia. Stąd wynika konieczność ich racjonowania. Niedofinansowanie systemu zdrowotnego prowadzi więc do niedoboru podaży świadczeń w stosunku do potrzeb zdrowotnych pacjentów. Niedostateczna ilość środków finansowych w systemie powoduje ustalanie limitów świadczeń, co wpływa na tworzenie się kolejek oczekujących. Na świadczenia (dotyczy to przede wszystkim leczenia specjalistycznego) czeka się zbyt długo, biorąc pod uwagę potrzebę skorzystania z opieki zdrowotnej. Pacjenci chcąc szybciej dostać się na wizytę do lekarza mogą albo zapłacić za świadczenie, korzystając z sektora prywatnego, bądź „,przeskakując” kolejkę, próbować przyspieszyć dokonanie zabiegu lub operacji poprzez ,nieoficjalne załatwienie”. Istnienie zjawisk korupcyjnych w celu uzyskania szybszego dostępu do opieki zdrowotnej można ograniczać, ustalając kolejność przyjęć do lekarza. W polskim systemie zdrowotnym zarówno wymogi systemu zarządzania jakością ISO 9001, jak i akredytacji nakazują monitorowanie kolejności na zabiegi. Jednakże sama decyzja dotycząca kwalifikacji do leczenia jest już arbitralną decyzją lekarza.

Sytuację niedoboru środków finansowych na opiekę zdrowotną w polskim systemie zdrowotnym potęguje istnienie płatnika monopolisty wyceniającego też procedury medyczne. Za ponadlimitowe świadczenia, czyli tzw. nadwykonania NFZ płaci jedynie wtedy, gdy uzna, że dane świadczenie było niezbędne dla ratowania życia pacjenta.

Limitowanie świadczeń wpływa nie tylko na pogorszenie dostępności opieki, ale i na obniżenie jej jakości. To właśnie jakość opieki zdrowotnej jest kolejną przesłanką wręczenia korzyści przez pacjentów. Na jakość składają się nie tylko warunki opieki (wyposażenie techniczne gabinetów i szpitali, warunki pobytu w szpitalu), ale i stosunek personelu medycznego do pacjenta (troskliwość, zainteresowanie, zwracanie uwagi na jego potrzeby i przestrzeganie jego praw). Niska jakość opieki (podobnie jak ograniczenia w jej dostępności) może wynikać przede wszystkim z niedoboru środków finansowych, co z kolei przekłada się na niedostateczną liczbę personelu medycznego. Sytuacja, w której na poszczególnych oddziałach stosuje się normy dotyczące liczby pacjentów przypadających na jedną pielęgniarkę (na intensywnej terapii jest to 2 chorych, na oddziałach zabiegowych - 4, a na zachowawczych 6) ma miejsce jedynie wtedy, gdy formą zatrudnienia jest umowa o pracę. Norm zatrudnienia nie stosuje się w tych podmiotach leczniczych, gdzie podstawową formą zatrudnienia są umowy cywilnoprawne, czyli kontrakty. Innym powodem złej jakości opieki może być niewystarczająca infrastruktura szpitalna i brak nowoczesnego sprzętu medycznego. Na niską jakość opieki może wpływać też specyficzny mechanizm opłacania świadczeniodawców, jaki istnieje w ochronie zdrowia. Tradycyjny typ relacji ekonomicznych, w których producent za konkretną usługę wyświadczoną konsumentowi jest przez niego wynagradzany, zostaje zastąpiony pośrednikiem, którym w ochronie zdrowia jest płatnik. Wynika to z przejęcia przez państwo odpowiedzialności za zdrowie obywateli. Prawo do opieki zdrowotnej przysługuje wszystkim obywatelom (niezależnie od sytuacji finansowej i wysokości środków, które zostały od nich pobrane). Odpowiedzialność państwa za opiekę zdrowotną przybiera formę obowiązkowych ubezpieczeń zdrowotnych (składki) bądź finansowania systemu z podatków. Dodatkowym powodem istnienia pośrednika jest założenie, że ochrona zdrowia jest dziedziną, w której konsument nie jest w stanie podjąć racjonalnej decyzji dotyczącej ceny, jaką należałoby zapłacić za uzyskane dobro. Rolę finansowania przejmuje więc płatnik. Pobiera on od konsumenta (świadczeniobiorcy) środki finansowe, żeby opłacić producenta (świadczeniodawcę, lekarza) za wykonane świadczenie (retrospektywne metody finansowania opieki zdrowotnej) lub przed jego wykonaniem (prospektywne metody finansowania opieki zdrowotnej). Zmiana wspomnianej relacji ekonomicznej powoduje, że wynagrodzenie, które otrzymuje lekarz nie jest bezpośrednio powiązane $z$ wykonywanym świadczeniem, lecz zależy od decyzji płatnika. Dodatkowo nowe sposoby finansowania świadczeń szpitalnych (np. Jednorodne Grupy Pacjentów) uzależniają opłacanie świadczenia od wykonania procedur, wpływając na ograniczenie długości pobytu pacjenta w szpitalu. Może więc zaistnieć sytuacja polegająca na tym, że uwaga świadczeniodawców skupia się na zaspokojeniu wymagań proceduralnych, a nie na pacjencie. W związku z tym świadczeniobiorca (szczególnie ,ponadlimitowy”) zamiast być podmiotem systemu, może znaleźć się na drugim planie oraz stać się dla świadczeniodawcy ciężarem powodującym dodatkowe koszty i będącym kolejną przyczyną jego zadłużania się. Świadczeniodawcy finansowani ze środków publicznych nie są więc zmotywowani do polepszenia jakości opieki, a pacjenci, których nie stać na opiekę prywatną, będą korzystać z sektora publicznego nawet wtedy, gdy nie są zadowoleni z jego usług. Na jakość opieki zdrowotnej wpływa również kwestia wysokości wynagrodzeń pracowników ochrony zdrowia. Poczucie lekarzy, że są słabo opłacani, może być przyczyną podatności na potencjalne propozycje korupcyjne. Temu procederowi sprzyja sposób finansowania pracowników ochrony zdrowia w publicznych podmiotach leczniczych. Dyrektor otrzymuje środki finansowe, które musi przeznaczyć zarówno na sfinansowanie zakontraktowanych 
świadczeń, jak i na wypłatę wynagrodzenia dla pracowników. Zwiększenie wydatków w jednej puli spowoduje zmniejszenie ich w drugiej. Każda z sytuacji będzie więc korupcjogenna. Mniej środków na wynagrodzenia może oznaczać większą podatność pracowników na przekupstwo, a związane z tym pogorszenie jakości opieki może dodatkowo zachęcić pacjentów do przekupstwa.

Z drugiej strony zwiększenie poziomu wynagrodzeń i uszczuplenie środków na świadczenia może doprowadzić do pogorszenia dostępności opieki i wpływać na potencjalną korupcję. Niezadowolenie lekarzy z zarobków w sektorze publicznym może być jednym z powodów podejmowania przez nich zatrudnienia w sektorze prywatnym. Łączenie zatrudnienia może wpływać negatywnie na cały system ochrony zdrowia, przyczyniając się do zwiększenia zjawiska korupcji. Praca na kilku etatach może spowodować, że lekarze zaniedbają pracę w publicznym podmiocie leczniczym (skracanie godzin przyjęć), co jednocześnie wpłynie na obniżenie standardów opieki. Lekarze mogą w ten sposób zachęcać pacjentów (świadomie i nieświadomie) do skorzystania z płatnych usług w ich prywatnym gabinecie bądź do zaoferowania łapówki. Mechanizm opłacania świadczeniodawców czy też kwestia niskich zarobków pracowników ochrony zdrowia mogą rzutować na postawę korupcyjną lekarzy w stosunku do pacjenta, choć nie są jej jedynymi powodami. Innymi przyczynami są: brak właściwej edukacji na studiach medycznych, brak odpowiednich walorów moralnych, brak powołania do wykonywania zawodu oraz brak poczucia posłannictwa swego zawodu. Z kolei brak satysfakcji z opieki zdrowotnej może powodować u pacjenta wspomniane poczucie powinności korupcji wynikające z wątpliwości, czy świadczeniodawca zapewni mu opiekę o jak najwyższym standardzie.

Za zachowania korupcyjne uważa się też kwestię dodatkowego „wynagradzania” lekarzy przez pacjentów. Jest to związane $\mathrm{z}$ historycznym funkcjonowaniem tradycyjnego modelu zawodu lekarskiego jako wolnej praktyki. Model ten wraz ze specyficznością posługi lekarza (ratowanie życia i zdrowia) spowodował zakorzenienie się poglądu, że lekarzowi za opiekę należy się zapłata bądź inny dowód wdzięczności, np. prezent. Pogląd ten nierzadko funkcjonuje obecnie.

Istnieją wątpliwości, czy wręczenie prezentu można traktować jako korupcję. Kryteriami korupcji mogą być: czas wręczenia prezentu, jego wartość i charakter. Z logicznego punktu widzenia wręczenie drobnego podarunku w ramach wdzięczności nie spełnia przesłanek korupcji. Jednakże organy ścigania czy też sądy w swych orzeczeniach mogą interpretować jako korupcję także tę formę podziękowania. Taką postawę organów ścigania można tłumaczyć tym, że dawanie prezentu interpretują jako potencjalną ,zaliczkę" przed następną wizytą.

Skala nieoficjalnych wydatków na opiekę zdrowotną była przedmiotem badań raportu Diagnoza Społeczna ukazującego się co 2 lata i badającego warunki oraz jakość życia Polaków. Według raportu wydatki związane z tzw. opłatami nieformalnymi ponosiło $1,4 \%$ badanych gospodarstw domowych (w $2011 \mathrm{r}$. było to 1,7\%), natomiast wydatki na prezenty, czyli dowody wdzięczności ponosiło 1,9\% gospodarstw (w 2011 r. 1,6\%).

Szacowana średnia roczna wysokość wydatków na opłaty nieformalne w gospodarstwach domowych wynosiła 273 zł (w 2011 r. - 311 zł), natomiast średnia roczna wysokość wydatków związanych ze szczerymi dowodami wdzięczności wręczanymi za już uzyskaną opiekę wyniosła średnio 128 zł (w 2011 r. - 142 zł) [5].

Odsetek gospodarstw domowych, w których osoby badane przyznały, że wydają środki na opłaty nieformalne i prezenty nie jest wysoki, ale należy pamiętać o tym, że odpowiedzi nie zawsze muszą być w tej kwestii szczere.

\section{Korupcja w relacjach lekarzy z przemysłem medycznym}

Kolejny typ powiązań korupcyjnych w ochronie zdrowia, mimo że nie dotyczy bezpośrednio relacji między lekarzem a pacjentem, może mieć na nie wpływ. Poczucie satysfakcji pacjenta $z$ opieki zdrowotnej może być związane $\mathrm{z}$,dostępnością cenową" oraz wskazaniami do stosowania danego leku.

Zachowanie korupcyjne w relacji lekarza z przemysłem medycznym polega na tym, że pracownik przemysłu farmaceutycznego zachęca lekarza do przepisania pacjentowi leku określonej firmy. Sytuacja taka może mieć miejsce wtedy, gdy lekarz prowadzi praktykę jako lekarz rodzinny czy specjalista i od jego decyzji zależy, jaki lek przepisze lub będzie stosował w leczeniu szpitalnym. Wśród prób korumpowania i lobbingu istnieją przypadki organizowania wyjazdów lub darmowych szkoleń mające na celu „zachęcenie" lekarzy do stosowania określonego leku, dostarczania próbek produktów lub wyposażenia gabinetów. Firmy medyczne działając w ten sposób, oczekują przyszłych korzyści w postaci stosowania ich produktów przez lekarzy.

Gdy lekarz występuje jednocześnie jako badacz i wykładowca wówczas narażony jest ze strony producenta leku czy sprzętu medycznego na propozycje korupcyjne. Mogą one przybierać formę zamawiania badań i prac naukowych dotyczących stosowania danego produktu. Propozycja korupcyjna może zmierzać do zafałszowania badań lub ukrycia ich wyników. Sytuacje takie mogą mieć miejsce podczas wprowadzania nowego leku na rynek. Największe konsekwencje korupcji w tym sektorze mogą wystąpić, gdy lekarz jest konsultantem oraz urzędnikiem na szczeblu wojewódzkim lub krajowym i ma wpływ na decyzje dotyczące stosowania określonego leku albo procedury medycznej.

Szczególnie nieetyczną formą korupcji i oszustwa jest proceder polegający na tym, że firmy zachęcają szpitale do stosowania wyprodukowanego przez siebie leku, przekazując pierwsze jego partie bezpłatnie. Są to najczęściej leki 
innowacyjne i w związku z tym kosztowne oraz nie zawsze refundowane. Leki te stosowane są najczęściej w leczeniu niestandardowym, w którym chorych na nowotwory poddaje się leczeniu nowym lekiem, gdy dotychczasowe leczenie nie przynosi rezultatu. Producent $w$ trakcie leczenia wycofuje się ze sponsorowania leku. Pacjent i lekarz prowadzący są już wtedy ,uzależnieni” od stosowania leku, dlatego chcąc kontynuować leczenie, są jednocześnie zmuszeni do zakupu dalszych jego partii [6].

Powiązania korupcyjne lekarza z przemysłem medycznym mogą wpływać na decyzje dotyczące leczenia pacjenta i przyczyniać się do negatywnego wizerunku lekarzy wśród społeczeństwa.

\section{Skutki korupcji w ochronie zdrowia}

Negatywne skutki, jakie stwarza problem korupcji we współczesnej etyce medycznej, można rozpatrywać w aspektach: ekonomicznym, społecznym i etycznym.

W ujęciu ekonomicznym istotą korupcji jest strata, która może obciążać cały system zdrowotny (w przypadku korupcji między lekarzem czy urzędnikiem a przemysłem medycznym wielkość potencjalnych korzyści jest duża). Jednak to przede wszystkim pacjent, oprócz pobieranej składki zdrowotnej czy płaconych podatków, jest narażony na dodatkowe koszty. Korupcja prowadzi więc do podniesienia i tak już wysokiego w Polsce poziomu prywatnych wydatków na ochronę zdrowia.

Korupcja w aspekcie społecznym oznacza, że teoretyczne podstawy, na których oparta jest ochrona zdrowia (równość dostępu, sprawiedliwość) stają się fikcją, bo dostęp do opieki zdrowotnej jest uzależniony od finansów. Jeżeli więc zjawisko korupcji występuje w szerszym wymiarze, staje się problemem społecznym. Może on wynikać z rozprzestrzeniania się wśród pacjentów poglądu, że korumpowanie staje się niezbędne, co ma wpływ demoralizujący zarówno na pacjentów, jak i na lekarzy. Powodem zachowań korupcyjnych w społeczeństwie jest poczucie powinności jej stosowania u korumpowanego i korumpującego (,daję i biorę, bo wszyscy tak robią"), czyli nawyk dawania i brania, a nawet przekonanie o konieczności jej stosowania u korumpującego - ,jeśli tego nie zrobię, nie dostanę potrzebnej usługi” lub „dostanę tę usługę w gorszej jakości" [7]. Występuje tutaj utrata zaufania pacjentów do lekarzy (a także całego systemu ochrony zdrowia). Słysząc o ujawnianych przez mass media aferach korupcyjnych, pacjenci mogą mieć wątpliwości co do uczciwości lekarzy i co do tego, czy są przez nich otoczeni odpowiednią opieką. Może to powodować wśród pacjentów przekonanie, że lekarze są grupą zawodową szczególnie podatną na korupcję i skłonić do składania propozycji korupcyjnych.

Biorąc pod uwagę aspekt etyczny, korumpowanie pozwala otrzymać szybszy dostęp do świadczeń, ale jest nieuczciwe.

\section{Czy postępowanie pacjenta, który chce szybciej dostać się do lekarza można usprawiedliwiać?}

Jeśli tak, to tylko do pewnego stopnia, ponieważ jego korzyść odbywa się kosztem innych pacjentów. Sytuacja, w której ogólny stan pacjenta czy też jego samopoczucie lub odczuwany ból byłyby powodem do jak najszybszej wizyty u lekarza i uzyskania jak najlepszej opieki, a wspominane limity utrudniają lub uniemożliwiają tę wizytę, tłumaczy częściowo postępowanie pacjenta korumpującego lekarza.

Na kim więc spoczywa odpowiedzialność za korupcję? Można nią obarczyć zarówno korumpujących, jak i korumpowanych, gdyż zagrożenia oraz działania korupcyjne są związane z niewłaściwą postawą etyczną osób biorących udział w tym procederze. Jednakże sytuacje korupcyjne mogą wynikać nie tylko z ogólnego rozluźnienia norm moralnych i związanego z tym klimatu społecznego przyzwolenia na korupcję.

Częstotliwość występowania sytuacji korupcyjnych zależy także od tego, jak funkcjonuje system ochrony zdrowia. Odpowiedzialność spada też na stanowiących prawo i zarządzających systemem. Odpowiadają oni za kształt systemu, a korupcjogenny system stwarza warunki do nieetycznych działań.

\section{Ograniczanie korupcji}

Zasadnicza kwestia związana z korupcją dotyczy tego, w jaki sposób można by ją ograniczać oraz jej zapobiegać? Niezbędne wydaje się działanie w kilku obszarach.

Pierwszy dotyczy ogólnego przeciwdziałania korupcji. Działania te związane są z funkcją karno-śledczą (powołanie CBA). Monitorowanie zagrożeń, czego wyrazem jest powołanie przy Ministerstwie Zdrowia Zespołu do spraw przeciwdziałania oszustwom i korupcji w ochronie zdrowia, spełnia funkcję kontrolną oraz prewencyjną. Istotne wydaje się też uświadamianie społeczeństwa poprzez działalność edukacyjną i informacyjną, co czynią nie tylko instytucje państwowe (CBA, Agencja Bezpieczeństwa Wewnętrznego, policja), ale i organizacje pozarządowe (np. Transparency International).

Szczególnie istotna w zapobieganiu korupcji wydaje się być postawa etyczna lekarza. Należy pamiętać, że zawód lekarza wiąże się nie tylko z powołaniem, ale także z prestiżem społecznym. Dlatego też zachowania korupcyjne w tej grupie zawodowej mogą stanowić szczególnie demoralizujący przykład zarówno dla pozostałych lekarzy, jak i dla pacjentów. Wpływ na postawę lekarza wobec zagrożeń korupcyjnych mogą mieć nie tylko ukształtowanie do wykonywania zawodu i przestrzeganie jego zasad deontologicznych, ale też system wartości i cechy charakteru.

Kształtowanie postawy etycznej lekarzy powinno mieć miejsce już podczas studiów. Konieczna jest więc odpowiednia liczba godzin z etyki i nauk społecznych kształtujących zarówno postawę moralną, jak i uczących właściwych relacji 
interpersonalnych między lekarzem a pacjentem. Edukacja przyszłych lekarzy jest potrzebna, aby przyswajali oni sobie tradycyjne wartości moralne, jak: uczciwość, bezinteresowność, współczucie, troskę czy miłość bliźniego, które kiedyś były przekazywane wraz z wychowaniem w rodzinie i wpajane przez mistrzów - nauczycieli zawodu. Obecnie zauważalny bywa ich brak, co można wnioskować, słysząc o zjawiskach korupcji w ochronie zdrowia.

Wśród cech charakteru, które powinien posiadać lekarz, aby zachować odporność na pokusę korupcji, powinny znajdować się: powściągliwość wobec korzyści korupcyjnych, intelektualna uczciwość i roztropność, odwaga i asertywność (dotyczące badań naukowych i kontaktów z przemysłem medycznym), poczucie sprawiedliwości i empatia w stosunku do pacjentów.

W polskim systemie ochrony zdrowia zasady deontologiczne dotyczące korupcji są zawarte w dwóch artykułach Kodeksu Etyki Lekarskiej. Artykuł 68 mówi o korupcji w relacjach z pacjentem: ,Jeżeli z zatrudnienia lekarza wynika, że winien on spełniać swe obowiązki wobec powierzonych jego opiece chorych bez świadczeń finansowych z ich strony, to nie może żądać od tych chorych wynagrodzenia w jakiejkolwiek formie, ani też uzależniać leczenia od uzyskania materialnych korzyści”.

Artykuł 51 traktuje o relacjach z przemysłem medycznym. W podpunkcie 51a zawarta jest ogólna klauzula: „Lekarz nie powinien przyjmować korzyści od przedstawicieli przemysłu medycznego, jeżeli może to ograniczyć obiektywizm jego opinii zawodowych lub podważyć zaufanie do zawodu lekarza". Kolejne podpunkty artykuły traktują o pożądanej postawie lekarza mającego związki z przemysłem medycznyn:

Artykuł 51d: „Lekarzowi mającemu związki finansowe z przemysłem medycznym nie wolno w żaden sposób odstąpić od podejmowania w pełni obiektywnych decyzji klinicznych lub działania w najlepszym interesie pacjentów i osób biorących udział w badaniach".

Artykuł 51e: „Lekarz powinien ujawniać swoje powiązania z producentem leków lub wyrobów medycznych (sprzętu i wyposażenia medycznego) pacjentom, którzy mają być poddani badaniom sponsorowanym przez tego producenta".

Artykuł 51f: „Lekarz nie może przyjmować wynagrodzenia za samo skierowanie pacjenta na badania prowadzone lub sponsorowane przez producenta leków lub wyrobów medycznych (sprzętu i wyposażenia medycznego)" [8].

Mówiąc o edukacji, należy pamiętać o społeczeństwie, czyli o potencjalnych pacjentach. Muszą oni mieć świadomość, że korumpując lekarzy, stabilizują patologie w systemie ochrony zdrowia.

Chociaż występowanie korupcji łączy się ze zdemoralizowaniem osób biorących w niej udział, to najistotniejszy w zniwelowaniu jej przyczyn wydaje się obszar regulacji dotyczący organizacji systemu ochrony zdrowia.
Problem niedoboru środków finansowych można by ograniczyć poprzez możliwość oficjalnych dopłat do leczenia w publicznym sektorze ochrony zdrowia. Co prawda podważałoby to w pewnym sensie równość dostępu do opieki zdrowotnej, ale reguły dostępu byłyby w tym wypadku wyraźniej określone. Konieczne byłoby szczegółowe określenie zakresu świadczeń gwarantowanych przez państwo obywatelem w ramach ubezpieczenia zdrowotnego, czyli tzw. koszyka świadczeń zdrowotnych, w którym płatnik określa procedury finansowane ze środków publicznych.

W Polsce od kilku lat przebiegają prace nad ustawą o dodatkowych ubezpieczeniach zdrowotnych, która miałaby wprowadzić je do publicznego sektora ochrony zdrowia. Ubezpieczenia te obejmowałyby świadczenia będące poza koszykiem świadczeń gwarantowanych. Wprowadzenie ich (podobnie jak oficjalnych dopłat, czyli tzw. współpłacenia) wiązałoby się zarówno z uzyskaniem szybszego dostępu do opieki zdrowotnej, jak i polepszeniem jej standardów. Ponadto po wprowadzeniu wspominanych rozwiązań do sektora publicznego wpłynęłaby dodatkowa ilość środków, które obecnie trafiają do kieszeni korumpowanych bądź do prywatnego sektora opieki zdrowotnej działającego poza umowami z NFZ.

Oprócz próby włączenia do systemu wydatków prywatnych niezbędne wydaje się zwiększenie publicznych wydatków na ochronę zdrowia, które mogą wpłynąć na polepszenie zarówno dostępności, jak i jakości opieki zdrowotnej.

\section{Piśmiennictwo}

1. Kodeks karny - Ustawa z dnia 6 czerwca 1997 r. DzU z 1997 r., nr 88, poz. 553. Internetowy System Aktów Prawnych. http://isap.sejm.gov. pl/DetailsServlet?id=WDU19970880553 (17.11.2013).

2. Suwaj P.J.: Etyka i świadomość zagrożeń korupcyjnych. Fundacja Rozwoju Demokracji Lokalnej, Warszawa 2011, 80.

3. Dobrzyński J.: Przewidywane zagrożenia korupcyjne w Polsce. https:// cba.gov.pl/pl/aktualnosci/2416,Przewidywane-zagrozenia-korupcyjne-w-Polsce.html (17.11.2013).

4. Informacja o wynikach działalności Centralnego Biura Antykorupcyjnego w 2012 r. http://cba.gov.pl/ftp/zdjecia/Sprawozdanie_2012. pdf (17.11.2013).

5. Czapiński J., Panek T: Diagnoza społeczna 2013. Warunki i jakość życia Polaków. Ministerstwo Pracy i Polityki Społecznej, Warszawa 2014, 114. http://analizy.mpips.gov.pl/images/stories/publ_i_raporty/DS2013/ Raport_glowny_Diagnoza_Spoleczna_2013.pdf(27.02.2014).

6. Potencjalne formy i obszary występowania oszustw i korupcji w ochronie zdrowia. Ministerstwo Zdrowia. Zespół do spraw przeciwdziałania oszustwom i korupcji w ochronie zdrowia. http://www2.mz.gov. pl/wwwfiles/ma_struktura/docs/zal_5_poszustwoz_19102007.pdf (17.11.2013).

7. Suchorzewska J., Michowska M.: Wybrane zagadnienia etyki lekarskiej z elementami prawa w medycynie. Akad Med w Gdańsku, Gdańsk 2006, 152.

8. Kodeks Etyki Lekarskiej. http://www.nil.org.pl/dokumenty/kodeks-etyki-lekarskiej (17.11.2013). 